\section{Birlesik Dünya Arastırma New Trends and Issues BD-CENTER Proceedings on Humanities and Innovasyon ve Yayıneılık Merkezi \\ Social Sciences}

Volume 7, Issue 3, (2020) 83-93

\title{
Fostering integration through Malay literature teaching among the Malaysian secondary school students
}

Fong Peng Chew*, Department of Language \& Literacy Education, Faculty of Education, University of Malaya, University Road, Kuala Lumpur 50603, Malaysia https://orcid.org/0000-0002-7876-7979

\section{Suggested Citation:}

Chew, F. P. (2020). Fostering integration through Malay literature teaching among the Malaysian secondary school students. New Trends and Issues Proceedings on Humanities and Social Sciences. 7(3), pp 83-93. Available from: www.prosoc.eu

Received from July 12, 2020; revised from September 10, 2020; accepted from November 01, 2020.

Selection and peer review under responsibility of Prof. Dr. Huseyin Uzunboylu, Higher Education Planning, Supervision, Accreditation and Coordination Board, Cyprus.

()2020 Birlesik Dunya Yenilik Arastirma ve Yayincilik Merkezi. All rights reserved.

\begin{abstract}
In the context of a multi-ethnic and multicultural country such as Malaysia, national integration is the fundamental pillar of the country's harmony and stability. Accordingly, this study aimed to investigate the extent to which the Malay Literature education enhances the integration among the students. On the basis of Weiner's theory, the study employed the questionnaire survey method. The respondents consisted of 310 secondary school form two students in Kuala Lumpur. The findings show that the Malay Literature textbooks do not reflect the multi-ethnic society in Malaysia. Furthermore, the teachers were struggling to stimulate the interests among the students, and the interest of the latter to learn Malay literature was low. Inferential analysis indicated significant differences in unity literature education based on the ethnicities $[F(2.307)=34.573 ; p<0.05]$ and SES $[F(3.306)=5.109 ; p<0.05]$. In conclusion, Malay literature education plays its unique role to instil the sentiment of unity among the students in the school setting. Therefore, teachers should come up with interesting teaching methods to cultivate students' interest in learning the unity-themed literature and grant them a better understanding of other ethics in the effort to boost national integration.
\end{abstract}

Keywords: Malay language, Malay literature, national integration, unity literature.

\footnotetext{
* ADDRESS FOR CORRESPONDENCE: Fong Peng Chew, Department of Language \& Literacy Education, Faculty of Education, University of Malaya, University Road, Kuala Lumpur 50603, Malaysia.

E-mail address: fpchew@um.edu.my
} 


\section{Introduction}

In multi-ethnic and multicultural countries, national integration has become an important pillar of the nation's stability, such as China (Wang \& He, 2014), Australia (McAllister, 2016), post-Soviet nations (Letnyakov, 2016), India (Midatala, 2018) and Italy (Bisin \& Tura, 2019). Malaysia as one of the ethnically diverse countries consists of three main ethnicities, namely Malay, Chinese and Indian. Apart from these three main ethnic groups, Malaysia is also home to approximately 80 other ethnic groups, such as Kadazan-Dusun, Bajau, Iban and so on (Department of Information Malaysia, 2017). Consequently, the people pursue different religions, such as Islam, Buddhism, Hinduism, Christianity and so on. The Malaysian society also has unique customs and cultures other than practicing their own ethnic identity.

Omodan and Tsotetsi (2019) stated that education is a prior sector in every well-meaning society. In addition, education serves as a major force in promoting national integration and creating a cohesive national identity (Segawa, 2019). In line with this concept, the Malaysian education system is chosen as a key medium in fostering a sense of integration among the younger generation, especially among students in the school. The national education system plays a role in educating the heirs of the nation to be knowledgeable and to inculcate positive values in the students to foster national integration. Such a system of education must be implemented according to the needs and suitability of a multiethnic society to function properly as a medium that fosters a strong sense of unity within the nation.

Within the ethnically and religiously diverse secular state of Malaysia, ethnicity (Tee, 2015) and religion (Fernandez \& Coyle, 2019) have always been categorised as sensitive issues in the nation's development history. Therefore, understandings of other religions and practices must be implemented to avoid misconceptions or misunderstandings among the multi-ethnic groups that could cause public order disruption. Malaysia has established a framework of policies, including the Rukunegara (Nation Principle), National Education Policy, National Language Policy, National Cultural Policy, National Youth Policy and New Economic Policy, to discourage disputes and bolster national integration.

In the education system, the Malay Language as the medium of instruction plays an important role to instil understanding among multi-ethnic students. In 2001, the Ministry of Education (MOE) initiated the crafting of the Literature Component (LC) in the Malay Language to foster harmony and prosperity in the society (Omar, 2015). According to Hashim, Mohd Nasir, Ismail, Mat Hussain and Tahir (2018), selecting the LC texts showed that the selection process for the LC textbook is based on the criteria that meet three main dimensions. The dimensions on request comprise the material dimensions requiring the selected text to be of good quality, appropriate and consistent with the national curriculum. The second is the dimension of the teacher. A selected textbook should be implemented by the teacher in the teaching and learning process. Therefore, the text must be in line with the teacher's expertise in delivering the lesson to the students. Finally, student dimension focuses on texts that are easily understood, close to students' life, engage them, sparks their creativity and in turn makes the text accessible to them. The student dimension is a very important aspect as it is a visible result of whether the text of the commentary leads to a positive effect or vice versa.

Implementing the Malay Literature Component (MLC) will produce future generations with a credible and strong identity, as literature reflects the reality of functional relations in a multi-ethnic society, especially in school. According to Arshad, Othman and Awang Da (2011), Malay literature indeed plays an important role in fostering integration, harmony, understanding and prosperity among the people in Malaysia. In addition, literature plays its role to inculcate among students a sense of unity, thereby allowing them to relate across both ethnic and religious divisions and espouse ideals as people with a common destiny (Bello \& Okpiliya, 2017).

Despite the implementation of educational literature, particularly MLC, it should be viewed from a variety of perspectives when evaluating the effectiveness of its implementation to instil integration among students. Effectiveness can be measured by looking at the ability of teachers and acceptance of 
students to discover the $C L$ texts that cover varieties of core elements in life as key issues (Awang, Abdul Rahman, Mohd Amin \& Ahmad, 2015).

Nowadays, teachers tend to teach MCL by using a structure-guided approach, which analyses the internal aspects of literary texts in terms of themes, characters, plot, setting and language style. This process has led to the undermining of the role of literature education in promoting national integration among the students (Chew, 2006). According to the study of Chew (2009), the textbook of $\mathrm{MCL}$ did not reflect the reality of multi-ethnic society in Malaysia. In addition, students tend not to make friends with those from other ethnicities. They showed low interest in learning $M C L$ in which thinking was Malay-centred. Conversely, educators who teach language subjects rarely associated the elements of national integration to daily learning either in or outside the classroom (Chew, 2009; Yong, Ku Samsu, Adnan, David \& Ab Halim, 2018).

Furthermore, Arshad et al. (2011) agreed that studies in the field of multicultural literature or the literature theme on integration in Malaysia are not as rapid as those in Western countries. Thus, information, studies on developments and the latest data on the integration of multi-ethnic society are lacking, especially in Malay Literature. In this context, Malay Literature, as the national literature, plays its unique role to reflect the real life of multi-ethnic, multicultural and multi-religious groups of the country. Therefore, the introduction of MLC in the Malay Language subject among others ultimately aims to improve and foster positive values such as mutual respect and understanding among different ethnic groups and solidarity as the end means.

Literary education also contributes to the development of students' personalities, regardless of their ethnicities, culture and religions. Creating a compelling personality can be nurtured through positive thinking as well as embracing a storyline based on the core values reflected by the authors in their work. Literary education not only shapes the character of a student, it also enhances their literary skills. As such, the absorption of elements of one another's cultural diversity can be directly explored and appreciated in shaping Malaysia's sensitivity to other peoples' cultures, especially multiethnic nations. Therefore, literary education must be strengthened as a core of teaching and learning in the school so that students can better understand the art of solidarity in the students' minds. Literary education that has long been implemented in education is also seen to boost the spirit of unity among the students in schools. Therefore, this study focuses on literary education through LC textbooks and practical implementation. It also investigates the differences in the implementation of literary education on the basis of social background.

\section{Research questions and hypotheses}

The current research raises the following questions:

1. How frequent are the elements of unity mentioned in the $C L$ textbook?

2. What is the implementation condition of the unity literature teaching?

3. Do any significant differences exist between the implementation of unity literature teaching and ethnicities and SES?

According to the research questions, two hypotheses are developed as follows:

H01: No significant difference exists between the implementation of unity literature teaching and ethnicities.

H02: No significant difference exists between the implementation of unity literature teaching and family income/SES.

\section{Theoretical framework}

According to Weiner's theory (1965), national integration meant 'a process of bringing together...into a single territorial unit and establishment of national identity'. Furthermore, Weiner 
(1965) stated that national integration is a step towards unifying a divided society into an ongoing unified process that fosters a sense of obedience to the nation

This study found that in Malaysia, the process of achieving unity or integration of different ethnicities is not a distant dream; it can be achieved through mutual understanding and respect. However, achieving a greater national harmony and integration in the modern world is not possible without a strong spirit of nationalism. In addition, the spirit of the narcissism of every citizen in this country is guided by mutual interests and identities. In this context, Malaysia uniquely achieves cultural integration and behavioural integration. The diversity of cultural activities carried out in social activities can strengthen the bond of unity among people of different backgrounds. As an example, during the festival celebration, the Malaysians implement the 'open house', and celebration of Independence Day is organised to involve all ethnicities in Malaysia.

In determining steps to build community cohesion, the researcher developed the concepts of LC text suitability, teacher commitment as a teaching force and student acceptance in the teaching and learning process of LC through Weiner's theory (see Figure 1).

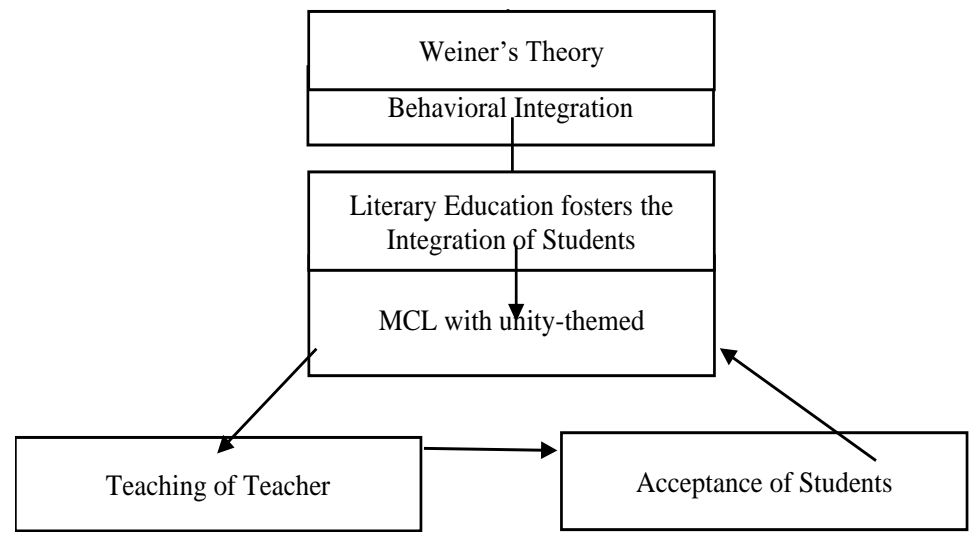

Figure 1. Theoretical framework of literary education to instil integration of form two students

This study aims to examine the extent to which the LC themed on unity is taught to develop a strong sense of solidarity among the secondary school students based on the National Integration Theory, pioneered by Weiner (1965). The theory comprises four parts: region integration, cultural value integration, mass-elite integration and behavioural integration. In this study, behavioural integration was applied to develop the questionnaire. According to Weiner (1965), behavioural integration aims to be the scope of society in forming an organisation for a common benefit. In the scope of this study, the researcher focused on three aspects, namely textbooks, teachers and students. The appropriateness of the textual materials implemented in the teaching and learning of the MLC should also be emphasised in terms of age appropriateness and appropriate for reading at the school level (Hashim et al., 2018). Therefore, literary text selection for secondary schools should suit or represent young people, encourage them to build good character and foster a sense of belonging in a multi-ethnic society.

From teachers' viewpoint, teaching well is essential as it serves as a benchmark of effective teacher practice in teaching and learning to improve the level of excellent teachers' professionalism (Chong, Abdul Ghani \& Abdullah, 2016), including language teachers, especially in teaching MLC. The quality of teaching is evaluated by the quality of the information and the teacher's willingness to convey the teaching to increase the students' interest in learning and understanding the lessons learned. The teaching level here refers to the appropriateness of teaching of the teacher to the students' ability level as well as the readiness of the students to master the knowledge conveyed by the teacher. From the students' standpoint, acceptance is an important aspect of ensuring successful teaching and learning. The acceptance of the students focuses on their desire and willingness to accept the 
knowledge taught by the teacher. Students must understand the instruction and delivery by the teacher through perseverance and understanding as they learn. Figure 1 shows the researcher incorporating the concepts involved, such as the appropriateness of unity-themed CL texts, the central role of the teacher and the acceptance of students in the learning process in schools.

\section{Methodology}

This study employed a survey method with a questionnaire as the research instrument. This study was conducted in six selected secondary schools in Kuala Lumpur. The simple random sampling method was implemented in the study to select a total of 310 Form Two students.

The researchers adapted Chew's (2009) questionnaire to answer the research questions developed in this study. The questionnaire contained three parts. Part I comprises the demography of the respondents, including ethnicity, gender, religion and family monthly income (SES). Part II consists of 16 items of $C L$ texts pertaining to the elements of unity, while Part III was mainly surveying 13 items of implementation of the unity literature teaching.

A pilot study was conducted on 30 Form Two students at one national secondary school in Kuala Lumpur. Cronbach's alpha value was 0.85 , indicating that the instrument was consistent and reliable. Accordingly, it was distributed to the selected respondents in the actual study. Subsequently, data from the questionnaire were analysed by using Statistical Package for the Social Sciences. Collected data $(n=310)$ have undergone the normality test: skewness $(-0.29$ to +0.64$)$ and kurtosis $(-1.46$ to +0.60 ) showed that data were distributed normally, indicating that parametric test can be applied in the data analysis.

\section{Profile of respondents}

Table 1 shows the distribution of the respondents.

Table 1. Background of the respondents

\begin{tabular}{llcc}
\hline \multicolumn{1}{c}{ Category $(\boldsymbol{n}=\mathbf{3 1 0})$} & \multicolumn{1}{c}{ Description } & Frequency & Percentage (\%) \\
\hline Gender & Males & 157 & 50.5 \\
& Females & 153 & 49.5 \\
Ethnic & Malay & 109 & 35.2 \\
& Chinese & 108 & 34.8 \\
\multirow{5}{*}{ Religions } & Indians & 93 & 30 \\
& Islam & 109 & 35.2 \\
& Buddhism & 102 & 32.9 \\
& Hinduism & 84 & 27.1 \\
Family monthly income/SES & Christian & 15 & 4.8 \\
& Less than RM1,000 & 100 & 32.3 \\
& RM1,001-RM3,000 & 102 & 32.9 \\
& RM3,001-RM6,000 & 51 & 16.5 \\
& More than RM6,001 & 57 & 18.4 \\
\hline
\end{tabular}

From Table 1, the number of males (157 students; $50.5 \%$ ) was nearly equal to the number of females (153 students; 49.5\%). In terms of ethnicity, a total of 109 students (35.2\%) and 108 students (34.8\%) were Malays and Chinese, respectively, whereas 93 students (30\%) were Indian. Similarly, all Malays (109 students; 35.2\%) were Muslims, 102 (32.9\%) were Buddhists and 84 students (27.1\%) and 15 students (4.8\%) were Hindus and Christians, respectively.

In terms of SES, out of the 310 respondents, 102 students (32.9\%) came from families with monthly incomes from RM1,001 to RM3,000, whereas 100 students (32.3\%) had a family monthly income of less than RM1,000. Furthermore, 51 students (16.5\%) had a family monthly income between RM3,001 
and RM6,000, while 57 students (18.4\%) had a family income above RM6,001. Looking at the household income of the respondents, the salary range between RM1,001 and RM3,000 ranked the highest number.

\section{Results and Discussion}

\subsection{Research question 1: How frequent are the elements of unity mentioned in the CL textbook?}

To answer research question 1, two LC textbooks were examined for Form Two students, namely Anthology of Good Characters, Beautiful Language and a novel titled, Pursue the Dream. The Anthology of Good Characters, Beautiful Language contained 14 texts, including five classical poems (Panton), one minstrelsy, three modern poems, one classical prose, three short stories and one drama. Table 2 shows the Form Two students' agreement level on the LC genre texts on the elements of unity.

Table 2. Frequency of the $C L$ texts pertaining to the elements of unity

\begin{tabular}{|c|c|c|c|c|c|c|c|c|}
\hline Num & Items & $S D$ & $D$ & $\boldsymbol{U}$ & $A$ & $S A$ & $M$ & $S D$ \\
\hline 1 & Panton of adolescent age & $9(2.90 \%)$ & 39 (12.60\%) & $135(43.50 \%)$ & $115(37.10 \%)$ & $12(3.90 \%)$ & 3.26 & 0.84 \\
\hline 2 & Panton of figuration & $9(1.90 \%)$ & 39 (12.60\%) & $172(55.50 \%)$ & $78(25.20 \%)$ & $15(4.90 \%)$ & 3.18 & 0.78 \\
\hline 3 & Panton of wisdom & $0(0 \%)$ & $15(4.80 \%)$ & $54(17.40 \%)$ & $136(43.90 \%)$ & 105 (33.9\%) & 4.07 & 0.84 \\
\hline 4 & Panton of advice & $3(1.00 \%)$ & $9(2.90 \%)$ & $54(17.4 \%)$ & $117(37.70 \%)$ & $127(41.00 \%)$ & 4.15 & 0.88 \\
\hline 5 & Panton of love & $15(4.80 \%)$ & 39 (12.60\%) & $120(38.70 \%)$ & $75(24.20 \%)$ & $61(19.70 \%)$ & 3.41 & 1.08 \\
\hline 6 & Minstrelsy of love & $30(9.70 \%)$ & $33(10.60 \%)$ & $153(49.40 \%)$ & $69(22.30 \%)$ & $25(7.80 \%)$ & 3.08 & 1.02 \\
\hline 7 & $\begin{array}{l}\text { In the surrounding of words } \\
\text { (modern poem) }\end{array}$ & $3(1.00 \%)$ & $12(3.90 \%)$ & $57(18.40 \%)$ & $114(36.80 \%)$ & $124(40.00 \%)$ & 4.11 & 0.90 \\
\hline 8 & Bread (modern poem) & $24(7.70 \%)$ & $39(12.60 \%)$ & $157(50.60 \%)$ & $66(21.30 \%)$ & $24(7.70 \%)$ & 3.09 & 0.98 \\
\hline 9 & $\begin{array}{l}\text { I am searching for peace here } \\
\text { (modern poem) }\end{array}$ & $12(3.90 \%)$ & $30(9.70 \%)$ & $66(23.30 \%)$ & 99 (31.90\%) & $103(33.20 \%)$ & 3.81 & 1.11 \\
\hline 10 & For a rose (modern poem) & $18(5.80 \%)$ & $63(20.30 \%)$ & $151(48.70 \%)$ & 54 (17.40\%) & $24(7.70 \%)$ & 3.01 & 0.96 \\
\hline 11 & $\begin{array}{l}\text { A deer is teaching an otter } \\
\text { (classical prose) }\end{array}$ & $69(22.30 \%)$ & $79(25.50 \%)$ & $144(46.50 \%)$ & $12(3.90 \%)$ & $6(1.90 \%)$ & 2.38 & 0.94 \\
\hline 12 & $\begin{array}{l}\text { Flood in the eyes of mother } \\
\text { (short story) }\end{array}$ & $27(8.70 \%)$ & $33(10.70 \%)$ & $157(50.60 \%)$ & $60(19.40 \%)$ & $33(10.60 \%)$ & 3.13 & 1.03 \\
\hline 13 & Tali and monster (short story) & $60(19.40 \%)$ & $61(19.70 \%)$ & $171(55.20 \%)$ & $18(5.80 \%)$ & $0(0 \%)$ & 2.47 & 0.87 \\
\hline 14 & Reap the gold (short story) & $18(5.80 \%)$ & $42(13.50 \%)$ & $142(45.80 \%)$ & $69(22.30 \%)$ & 39 (12.60\%) & 3.22 & 1.02 \\
\hline 15 & The court (drama) & $15(4.80 \%)$ & $15(4.80 \%)$ & 105 (33.9\%) & $90(29.00 \%)$ & 85 (27.40\%) & 3.69 & 1.07 \\
\hline \multirow[t]{2}{*}{16} & Pursue the dream (novel) & $24(7.70 \%)$ & $33(10.60 \%)$ & $159(51.30 \%)$ & $64(20.60 \%)$ & $30(9.70 \%)$ & 3.14 & 1.00 \\
\hline & Average score & & & & & & 3.32 & 0.95 \\
\hline
\end{tabular}

Table 2 shows the frequency of literary texts pertaining to the element of unity among Form Two students in Kuala Lumpur at a moderate level $(M=3.32, S D=0.95)$. This finding was due to other literary works compiled in the two-volume LC textbook of the Kuala Lumpur edition that inadequately embedded the value of unity in their text. As such, the ministry must increase the number of LC texts that embody the core value of unity to enable the effective nurturing of the sentiment of national integration within students.

The results of the study obtained from 310 Form Two students showed that the students gave the highest agreement on the genre text of 'Panton of Advice' $(M=4.15, S D=0.88)$ written by Harun Mat Piah. Some of the verses in this poem reflect the elements of national integration as shown below:

The Chinese child brought the letter,

From Perak heading to Deli;

Living in a world must be humble,

Language is not for sale. 
Banana sticks to eagles,

Fall into the pool at Inderagiri;

If you trade in a foreign region,

Better take good care of yourself.

(Excerpted from Anthology of Good Characters, Beautiful Language, 2014)

The theme of this Panton reflects the spirit of community life. The third and fourth verses mean we must behave in a civilised way while living in the world and that the language cannot be traded, whereas the seventh and eighth verses mean that settled foreigners are advised to be good when carrying their goods to other regions. The Panton brought pieces of advice to all the communities in Malaysia to respect the Malay language, the official language of the country. When a settled foreigner travels to another region, he should maintain a good behaviour and the country's good reputation. The theme in this poem also carries the meaning of doing good in life. Breaking the norms of society will lead to a ruined life.

The modern poems 'In the Surroundings of the Words' $(M=4.11, S D=0.90)$ and 'Panton of Wisdom' (M=4.07, $S D=0.84)$ are also widely accepted to have incorporated the elements of unity. Role play via a poem was supported by Williams and Adetayo (2017), who stated that poetry becomes a tool for promoting national integration and security of the nation.

By contrast, the traditional prose, 'A Deer is Teaching an Otter' $(M=2.38, S D=0.94)$ and short story titled 'Talia and the Monsters' $(M=2.47, S D=0.87)$ gained the lowest agreement in bringing the elements of unity from Form Two students. The results of this study are similar to those of Awang et al. (2015), where only a few proverbs related to the integration were selected in Form Four and Form Five Malay language textbooks.

From the above discussion, the literary genre pertaining to the most elements of solidarity could be concluded to be presented in Panton. Other literary genres such as traditional prose, poetry and short stories scarcely embedded the unity elements. Therefore, the MCL should multiply the elements of unity that can be used as the principle of life within the community.

\subsection{Research question 2: What is the implementation condition of the unity literature teaching?}

Table 3. Implementation of unity literary teaching

\begin{tabular}{|c|c|c|c|c|c|c|c|c|}
\hline Num & Items & $S D$ & $D$ & $\boldsymbol{U}$ & $A$ & $S A$ & $M$ & $S D$ \\
\hline 1. & $\begin{array}{l}\text { Unity literature teaching is implemented } \\
\text { during the school-based assessment. }\end{array}$ & $33(10.6 \%)$ & $30(9.7 \%)$ & $99(31.9 \%)$ & $97(31.3 \%)$ & $7(16.5 \%)$ & 3.33 & 1.18 \\
\hline 2. & Implemented outside the classroom & $15(4.8 \%)$ & $3(10.6 \%)$ & $108(34.8 \%)$ & $96(31.00 \%)$ & $89(18.7 \%)$ & 3.48 & 1.06 \\
\hline 3. & $\begin{array}{l}\text { Students ask questions to the teacher in the } \\
\text { classroom. }\end{array}$ & $9(2.9 \%)$ & $15(4.8 \%)$ & $57(18.4 \%)$ & $126(40.6 \%)$ & $103(33.2 \%)$ & 3.96 & .99 \\
\hline 4. & $\begin{array}{l}\text { The teacher is serious in teaching unity- } \\
\text { themed LC text in the classroom. }\end{array}$ & $6(1.9 \%)$ & $18(5.8 \%)$ & $81(26.1 \%)$ & $96(31.0 \%)$ & $109(35.2 \%)$ & 3.91 & 1.01 \\
\hline 5. & $\begin{array}{l}\text { The teacher can attract students' interest to } \\
\text { learn the unity-themed genre in LC } \\
\text { textbook. }\end{array}$ & $12(3.9 \%)$ & $24(7.7 \%)$ & 99 (31.9\%) & $99(31.9 \%)$ & $76(24.5 \%)$ & 3.65 & 1.05 \\
\hline 6. & $\begin{array}{l}\text { The teacher applies the elements of } \\
\text { integration among ethnic during the LC } \\
\text { teaching. }\end{array}$ & $28(9.0 \%)$ & $27(8.7 \%)$ & $96(31.0 \%)$ & $99(31.9 \%)$ & 60 (19.4\%) & 3.45 & 1.16 \\
\hline 7. & $\begin{array}{l}\text { LC texts embedded unity theme may be } \\
\text { easily understood by all ethnic students }\end{array}$ & $18(5.8 \%)$ & $48(15.5 \%)$ & $118(38.1 \%)$ & $81(26.1 \%)$ & 45 (14.5\%) & 3.28 & 1.08 \\
\hline 8. & $\begin{array}{l}\text { There are various interesting issues in the } \\
\text { LC text with the theme of integration. }\end{array}$ & $6(1.9 \%)$ & $27(8.7 \%)$ & $118(38.1 \%)$ & $108(45.8 \%)$ & $51(16.5 \%)$ & 3.55 & .94 \\
\hline 9. & LC textbooks cover all ethnics in Malaysia & $21(6.8 \%)$ & $12(3.9 \%)$ & $100(32.3 \%)$ & $102(32.9 \%)$ & $75(24.2 \%)$ & 3.64 & 1.10 \\
\hline
\end{tabular}


Chew, F. P. (2020). Fostering integration through Malay literature teaching among the Malaysian secondary school students. New Trends and Issues Proceedings on Humanities and Social Sciences. 7(3), pp 83-93. Available from: www.prosoc.eu

10. I am delighted to learn the LC texts that contain the theme of unity

11. I study positive values in LC text with the theme of unity

12. I often help friends to understand LC text that contains unity theme

13. I learn my friend's culture through LC teaching in classroom

Average score
$21(6.8 \%)$
$36(11.6 \%) \quad 78(25.2 \%)$
$87(28.1 \%)$
$88(28.2 \%) 3.601 .21$
$15(4.8 \%)$
$18(5.8 \%)$
$99(31.9 \%)$
$109(35.2 \%)$
$69(22.3 \%) 3.641 .04$
$15(4.8 \%)$
$15(4.8 \%)$
$103(33.2 \%)$
$130(38 \%)$
$57(18.4 \%) 3.611 .00$
$30(9.7 \%)$
$15(4.8 \%)$
$103(33.2 \%)$
$102(32.9 \%)$
$60(19.4 \%) 3.471 .15$

From Table 3, the implementation of unity literature teaching was at an average level $(M=3.59$, $S D=0.99$ ). Therefore, the implementation of the unity literature teaching requires improvement over time.

The findings of this study indicate that some items gained high agreement from Form Two students in this study. The statement, 'Students ask questions to the teacher in the classroom' $(M=3.96$, $S D=0.99)$, incited the highest and most positive agreement from Form Two students in this study. According to Mahamod and Lim (2011), when the observation was carried out on the secondary students in their studies, other questions were raised in the classroom during the MLC than in other lessons. The same result was found by Kurniawan, Abdullah, Zakaria and Wan Abdullah (2012) that students tend to ask questions in class if the topic was very interesting.

The second highest mean score of the statement fell on 'The teacher is serious in teaching unitythemed LC text in the classroom' $(M=3.91 ; S D=1.01)$. This finding showed that teachers were aware of the importance of delivering the literary text pertaining to elements of unity among the multiethnic students. This finding coincides with the results of Chew (2009) who found that the Malay Language teachers play a very important role in inculcating the spirit of goodwill among students through LC because ethnic integration is the cornerstone of national development. This result is also in line with the statements of Yong et al. (2018) and Segawa (2019) that teachers play a social role in shaping ethnic integration in schools.

By contrast, the statement 'LC text embedded unity theme may be easily understood by all ethnic students' ( $M=3.28 ; S D=1.08$ ) yielded the lowest mean values. Thus, understanding the choice of LC texts with the theme of unity was difficult for the students who come from different social backgrounds of religions and cultures because most of the LC texts on elements of unity consisted of Panton which is difficult to understand. Panton is a genre of traditional literature in which messages are conveyed implicitly through shadows and meanings and not through verbal means. In addition, Panton applied classical language and several metaphors which are difficult for students' understanding.

The statement, 'Unity literature teaching is implemented during the school-based assessment' $(M=3.33 ; S D=1.18)$, gained the lowest mean value as well. This finding demonstrated that Malay Language teachers give little attention to the unity theme in the school-based assessment. Indirectly, this finding suggested that teachers are less concerned with the topic of ethnic relations and integration as the focus of assessment in schools. This result can be attributed to the cautious attitude of teachers not to discuss sensitive issues related to ethnicity, religion and culture during the assessment.

The findings of this study showed that the students embraced a positive attitude towards the implementation of unity literature teaching in the classroom. However, improvements and strengthening must continue, given the lack of interest among students to study LC in the Malay language, the shortage of the LC texts on the theme of unity and the unattractiveness of the selected texts. This issue must be addressed effectively to enhance the quality of teaching and learning of LC. 


\subsection{Research question 3: Are there any significant differences between the implementation of unity literature teaching and ethnic and SES?}

The results of this question were analysed by using one-way analysis of variance (ANOVA). Table 4 shows the implementation of unity literature teaching based on ethnicities.

Table 4. One-way anova on the implementation of unity literature teaching based on ethnicities

\begin{tabular}{lcccccc}
\hline $\begin{array}{c}\text { Implementation of unity literature } \\
\text { teaching based on ethnic }\end{array}$ & Sum of square & $\boldsymbol{d f}$ & Mean square & $\boldsymbol{F}$ & $\boldsymbol{p}$ & $\boldsymbol{\eta ~ 2}$ \\
\hline Between group & 28.831 & 2 & 14.416 & 34.573 & $0.000^{*}$ & 0.184 \\
Among group & 128.006 & 307 & 0.417 & & & \\
Total & 156.837 & 309 & & & & \\
\hline
\end{tabular}

${ }^{*} p<0.05$

Table 5. Post-hoc Tukey's test on the implementation of unity literature teaching based on ethnic

\begin{tabular}{llccc}
\hline \multicolumn{1}{c}{ (I) Ethnic } & (J) Ethnic & Mean difference (I-J) & Std error & $\boldsymbol{p}$ \\
\hline Malay & Chinese & $0.688^{*}$ & 0.876 & 0.00 \\
Malay & Indians & $0.562^{*}$ & 0.0912 & 0.00 \\
Indians & Chinese & 0.126 & 0.913 & 0.354 \\
\hline
\end{tabular}

*Mean difference is significant at $p<0.05$.

The results of the one-way ANOVA test revealed that a significant difference exists between the implementation of ethnic literature teaching $[F(2,307)=34.573 ; p=0.00]$, and the effect size for between groups is medium $\left[\eta^{2}=0.184\right]$. Tukey's post-hoc test showed that the Malay group accepted the implementation of unity literature teaching statistically more than the Chinese group $(p=0.00)$ and Indian group $(p=0.00)$. No statistically significant difference existed between the Indians and Chinese groups $(p=0.354)$. Accordingly, the researcher concluded that the implementation of the unity-themed literature teaching was influenced by the ethnicity factor. Therefore, the first null hypothesis, 'There is no significant difference between the implementation of unity literature teaching and ethnic', was rejected.

Following the study conducted by Chew (2006), this situation occurred because the non-Malay students found the LC texts to be unattractive. For them, LC texts were Malay-centric in terms of story, characteristics or thinking. In line with this context, the findings affirmed the previous studies of Chew (2009), who showed significant differences of perception between the Malay students and other ethnicities on the literature pertinent to ethnic relations. Thus, this finding showed that ethnicity influences students' acceptance of literary works that carry the theme of unity.

Table 6 displays the result on the implementation of unity literature teaching based on SES.

Table 6. One-way anova on the implementation of unity literature teaching based on SES

\begin{tabular}{lcccccc}
\hline $\begin{array}{l}\text { Implementation of unity literature teaching } \\
\text { based on ethnic }\end{array}$ & $\begin{array}{c}\text { Sum of } \\
\text { square }\end{array}$ & $\boldsymbol{d f}$ & $\begin{array}{c}\text { Mean } \\
\text { square }\end{array}$ & $\boldsymbol{F}$ & $\boldsymbol{p}$ & $\boldsymbol{\eta} \mathbf{2}$ \\
\hline Between group & 7.481 & 2 & 2.494 & 5.109 & $0.002^{*}$ & 0.043 \\
Among group & 149.357 & 307 & 0.488 & & & \\
Total & 156.837 & 309 & & & & \\
\hline
\end{tabular}

$* p<0.05$.

Table 7. Post-hoc Tukey's test on the implementation of unity literature teaching based on SES

\begin{tabular}{ccccc}
\hline (I) SES & (J) SES & Mean difference (I-J) & Std error & $\boldsymbol{p}$ \\
\hline RM1,001-RM3,000 & Less than RM1,000 & $0.314^{*}$ & 0.093 & 0.005 \\
RM1,001-RM3,000 & RM3,001-RM6,000 & 0.144 & 0.116 & 0.599 \\
RM3,001-RM6,000 & Less than RM1,000 & 0.170 & 0.120 & 0.489
\end{tabular}




\begin{tabular}{llcll} 
More than RM6,000 & Less than RM1,000 & $0.442^{*}$ & 0.145 & 0.014 \\
More than RM6,000 & RM1,001-RM3,000 & 0.127 & 0.142 & 0.806 \\
More than RM6,000 & RM3,001-RM6,000 & 0.271 & 0.161 & 0.333 \\
\hline
\end{tabular}

*Mean difference is significant at $p<0.05$.

The results of the one-way ANOVA test revealed that a significant difference exists between the implementation of ethnic literature teaching $[F(2.307)=5.109 ; p=0.002]$, and the effect size for between groups is small $\left[\eta^{2}=0.043\right]$. Tukey's post-hoc test showed that students' family group who earned RM1,001-RM3,000 ( $p=0.005)$ and more than $\mathrm{RM6,000}(p=0.014)$ monthly accepted the implementation of unity literature teaching statistically more than the group which earned less than RM1,000 monthly. No statistically significant difference exists between RM1,001-RM3,000 and $\mathrm{RM} 3,001-\mathrm{RM} 6,000$ groups $(p=0.599), \mathrm{RM} 3,001-\mathrm{RM} 6,000$ and less than RM1,000 ( $p=0.489)$, more than RM6,000 and RM1,001-RM3,000 ( $p=0.806)$, more than RM6,000 and RM3,001-RM6,000 $(p=0.333)$. Therefore, the researcher concluded that the implementation of the unity-themed literature teaching was influenced by SES factor. Therefore, the second null hypothesis, 'There is no significant difference between the implementation of unity literature teaching and SES', was rejected.

Ethnic background of students appeared to be more influential than the SES variable in accepting the unity-theme teaching in the school context. These findings are similar to Nordin, Alias and Siraj (2017) who found that ethnoreligious-cultural backgrounds determine not only the strength of integration framework but also student preference for a specific integration framework or model.

\section{Conclusion and recommendations}

Creating and sustaining a shared sense of national integration is important in all societies, but it is especially crucial in the multi-ethnic countries, including Malaysia. The national literature, Malay Literature, plays an important role in building sub-ethnic cooperation and becomes the potential pathways towards a positive interfaith engagement. From the findings, students posed positive reaction to the literary works of Panton, poetry and drama in the secondary MLC textbooks in Kuala Lumpur. The implementation of the unity-themed literature teaching was at a moderate level. The findings indicated that ethnicities and SES factors influenced students' acceptance of unity-themed literature in the learning process.

The MOE, in its effort to bring about integration on the basis of the National Language Policy, has put in place the LC in the Malay language. To bolster the sentiment of integration, Malay Language teachers must become a role model by learning the culture and religions of others apart from mastering the literature teaching methods. This suggestion would probably command the respect of the students who would then understand better the importance of multiculturalism in maintaining respect and fostering intimacy among the different ethnic groups in school.

\section{References}

Arshad, M., Othman, A. J. \& Awang Da, N. (2011). The role of multicultural literature in the formation of national unity in Malaysia [translation]. Issues in Education, 34, 81-98.

Awang, M. M., Abdul Rahman, N. A., Mohd Amin, N. \& Ahmad, A. R. (2015). Integration message in form 4 \& 5 Malaysian langauge textbooks: analysis of Malay proverbs [traslation]. Malay Language Education Journal, 5(1), 44-52.

Bello, I. \& Okpiliya, J. O. (2017). Nigerian children's literature harnessing its potential for national integration. Brill, 49(1), 15-27.

Bisin, A. \& Tura, G. (2019). Marriage, fertility, and cultural integration in Italy. Cambridge, MA: National Bureau of Economic Research. Retrieved May 27, 2020, from https://www.nber.org/papers/w26303.pdf

Chew, F. P. (2006). Formation of the nation State through literary education [translation]. Jurnal Pengajian Melayu, 17, 136-168. 
Chew, F. P. (2009). Unity literary education through form four literature component in Malay language: its implementation and effects [translation]. Malaysian Journal of Education, 34(2), 15-31.

Chong, C. K., Abdul Ghani, M. F. \& Abdullah, Z. (2016). The practice of professional learning communities (PLC)) in Malaysia high achievement schools: a national-type Chinese school in Sarawak [translation]. JuPiDi: Journal of Educational Leadership, 3(1), 43-70.

Department of Information Malaysia, (2017). Statistic of Malaysian population. Cyberjaya, Malaysia: Malaysian Ministry of Communications and Multimedia.

Fernandez, E. F. \& Coyle, A. (2019). Sensitive issues, complex categories, and sharing festivals: Malay muslim students' perspectives on interfaith engagement in Malaysia. Political Psychology, 40(1), 37-53.

Hashim, N., Mohd Nasir, N. Y., Ismail, H., Mat Hussain, E. \& Tahir, N. S. (2018). Students' reception toward literature component text. Window Facing the Road [translation]. Pendeta Journal of Malay Language, Education and Literature, 9, 1-15.

Kurniawan, Y., Abdullah, T., Zakaria, K. \& Wan Abdullah, W. M. (2012). Why students are afraid to ask during lectures? A study in university Malaysia Kelantan [translation]. Malaysian Journal of Students Advancement, 15, 13-22.

Letnyakov, D. (2016). Nation-building: identity policies in Post-Soviet States. Mir Rossii-Universe of Russia, 25(2), $144-167$.

Mahamod, Z. \& Lim, N. R. (2011). Various methods of Oral Questioning in the teaching of Malay language teachers: an observation method [translation]. Malay Language Education Journal, 1(1), 51-65.

McAllister, I. (2016). National identity and attitudes towards immigration in Australia. National Identities, 20(2), 157-173.

Midatala, R. (2018). Linguistic diversity and national integration in India. Asian Journal of Development Matters, 12(1), 1-7.

Omar, A. (2015). Youth literature education in Malaysia in fostering excellant generations based on the State education philosophy. Pendeta Journal of Malay Language, Education and Literature, 5, 1-23.

Omodan, T. C. \& Tsotetsi, C. T. (2019). Framing ubuntu philosophy to reconstruct principals' behaviour and teachers' effectiveness in secondary schools. Journal of Education Research and Rural Community Development, 1(1), 25-45.

Segawa, N. (2019). Ethnic relations at school in Malaysia: challenges and prospects of the student integration plan for unity. Singapore: Springer Nature Pte Ltd.

Tee, M. R. (2015). Challenges of integration among the people in Malaysia: media, non-government organization and political parties perspectives [translation]. Journal Hadhari, 7(1), 33-59.

Wang, Z. J. \& He H. L. (2014). National identity in the era of globalization: crisis and reconstruction. Social Sciences in China, 35(2), 139-154.

Weiner, M. (1965). Political integration and political development. Annual of American Academy of Political and Social Science, 358, 52-64.

Williams, A. A. \& Adetayo, W. T. (2017). Poetry as atool for promoting national integration and security: a case study of the poem of oladele sangotoye "Etutu". Journal of African Studies, 27(3), 33-45.

Yong, H. H., Ku Samsu, K. H., Adnan, Z. H., Awang, M. D. \& Ab Halim, A. (2018). The role of teachers as socialization agents in forming integration in schools [translation]. Akademika, 88(2), 95-108. 